\title{
Ali Bahadori. "Achaemenid Empire, Tribal Confederations of Southwestern Persia and Seven Families"
}

\section{Salman Aliyari Babolghani}

\section{(2) OpenEdition \\ 1 Journals}

Electronic version

URL: http://journals.openedition.org/abstractairanica/50092

DOI: 10.4000/abstractairanica.50092

ISBN: 1961-960X

ISSN: 1961-960X

Publisher:

CNRS (UMR 7528 Mondes iraniens et indiens), Éditions de l'IFRI

\section{Electronic reference}

Salman Aliyari Babolghani, "Ali Bahadori. "Achaemenid Empire, Tribal Confederations of Southwestern Persia and Seven Families"'”, Abstracta Iranica [Online], Volume 40-41 | 2019, document 89, Online since 30 December 2019, connection on 21 April 2021. URL: http://journals.openedition.org/

abstractairanica/50092 ; DOI: https://doi.org/10.4000/abstractairanica.50092

This text was automatically generated on 21 April 2021.

Tous droits réservés 


\section{Ali Bahadori. "Achaemenid Empire, Tribal Confederations of Southwestern Persia and Seven Families"}

Salman Aliyari Babolghani 


\section{REFERENCES}

Ali Bahadori. “Achaemenid Empire, Tribal Confederations of Southwestern Persia and Seven Families”, Iranian Studies vol. 50, no.2, 2017, 173-197

1 Based on the Achaemenid sources (royal inscriptions and the Persepolis Fortification tablets) and Greek documentation, this article analyses the interrelation of the tribes in southwestern Persia and the Achaemenid kings. According to the author, the Achaemenid policy to control these tribal regions and to gain their support (e.g., in military alliances or for securing the royal road) was to establish tribal confederations headed by men loyal to the king such as Madates and Gobryas. The Great King reinforced these tribal confederations by political marriages and the subsequent awarding of imperial offices and economic privileges to tribal chiefs.

2 Bahadori presents some hypothesis related to the main topic of the article, such as: 1. suggesting that the royal woman Irdabama was the daughter of Gobryas (the chief of the Persian tribe Pātišuvariš/Patischorian and one of the seven allies of Darius I against Bardiya/Gaumāta) and a descendant of Hupan-ahpi of Šullaggi (a Neo-Elamite dynast in southwestern Persia, maybe in Fahliyān region) and as such she was married by Darius I following the aforementioned policy; 2. identifying the region Fahliyān or Shulestān (between modern Bāsht and Ardakān) as the territory of Patischorian tribe; 3. considering an Uxian origin for Sisygambis, the mother of Darius III, which could explain why she negotiated with Alexander to free the Uxians headed by Madates.

\section{AUTHORS}

\section{SALMAN ALIYARI BABOLGHANI}

Iran 